\title{
El archivo del cabildo colonial de la Ciudad de México. Fundación y símbolo de un nuevo orden
}

\author{
Alfonso Rubio Hernández*
}

Artículo recibido:

25 de octubre de 2018

Artículo aceptado:

21 de marzo de 2019

Artículo de investigación

\section{Resumen}

Tomamos como modelo los momentos iniciales de la fundación de la Ciudad de México en el siglo XVI para interpretar, desde unas coordenadas prácticas y simbólicas, la función del archivo o arca de tres llaves que la institución del Cabildo, Justicia y Regimiento de la ciudad estaba por ley obligada a instalar. La tradición burocrática que la Corona española traslada al Nuevo Mundo instaura mecanismos que desde el diseño de la traza urbana, la edificación del cabildo y el funcionamiento en él del arca de tres llaves legitiman un nuevo orden y garantizan la adhesión de la población a la administración hispana. Son estos mecanismos los que desde la documentación que custodia el propio archivo

* Departamento de Historia de la Universidad del Valle, Santiago de Cali, Colombia alfonso.rubio@correounivalle.edu.co

INVESTIGACIÓN BIBLIOTECOLÓGICA, vol. 33, núm. 81, octubre/diciembre, 2019, México, ISSN: 2448-8321 pp. 135-155 
del cabildo fundacional, hoy en día en el Archivo Histórico de la Ciudad de México, y desde una bibliografía que nos da pautas de interpretación, intentamos analizar en este texto.

Palabras clave: Archivo; Cabildo, Justicia y Regimiento; Fundaciones Coloniales; Ciudad de México

The archive of the Colonial Council of Mexico City. The foundation of a new order Alfonso Rubio Hernández

\section{Abstract}

The initial moments of Mexico City's foundation in the XVI century was taken as a model to interpret, from practical and symbolic coordinates, the function of the archive or arca de tres llaves that the institution of the Cabildo, Justicia y Regimiento of the city was required to install by law. The bureaucratic tradition that the Spanish Crown transfers to the New World, establishes mechanisms that legitimize a new order and guarantee the adhesion of the population to the Hispanic administration from the design of the urban layout, the building of the cabildo and the functioning of the arca de tres llaves. We tried to analyze these mechanisms from the documentation that keeps the archives of the founding council, nowadays in the Historical Archive of Mexico City, and from a bibliography that provided us some interpretation guidelines.

Keywords: Archive; Cabildo, Justicia y Regimiento; Colonial Foundations; Mexico City

\section{INTRODUCCIÓN}

$\mathrm{E}^{\mathrm{l}}$ proceso fundacional de centros urbanos en territorios de las Indias fue parte indispensable del control de la monarquía hispana. Los establecimientos de núcleos poblacionales, resultado de los procesos de conquista y colonización, trajeron consigo implicaciones sociales, políticas y económicas 
que se manifestaron en la instalación de un gobierno municipal, el mantenimiento de un sistema de estratificación social, que se da desde el mismo momento en el que se repartían los solares, así como en el otorgamiento de mercedes. De esta manera, el espacio urbano y la jurisdicción asignada a la nueva población, habitada previamente por naturales o no, se convertía en una unidad que debía ser gobernada y administrada.

Establecidos los asentamientos poblacionales, como condición real e instrumento de legitimación, las escrituras que fundan y destinan un espacio territorial en el Nuevo Mundo se convierten en el registro de las acciones de conquista y colonización que rigen las disposiciones de la Corona. Alineados a un conjunto de normativas y protocolos sobre las acciones a emprender en los nuevos espacios continentales, los fundadores de ciudades, villas y pueblos debieron crear pruebas de los logros alcanzados, ajustándose así a las disposiciones y reglamentos reales, pruebas que sólo podían establecerse y perdurar mediante acciones documentales.

Debido a la preponderancia política de la escritura en un imperio entonces sumamente burocratizado, su presencia en una formación social determinada o idealizada hacía posible articular y organizar todas las esferas sociales en la medida en que era el elemento necesario para gestionar y dar permanencia en el tiempo a todo un conjunto de actividades administrativas. Así, desde el primer momento, el documento escrito apareció como un instrumento no sólo legitimador, sino también controlador y organizador, que permitió dar coherencia a la gestión conquistadora y fundacional y que para ello, según lo establecido por la ley, debía custodiarse en el arca de tres llaves o archivo de la ciudad.

El "archivo básico" de las poblaciones recién creadas estuvo compuesto por aquellos documentos referentes a sus fundaciones, al desarrollo y la organización de unas protociudades y las consecuentes relaciones de jerarquización social que éstas establecían. Siempre en un lugar central de la ciudad, pero no visible, el archivo residía como última garantía del ejercicio del poder, como medio escriturario responsable de las actividades de la Corona y de sus representantes en el nuevo continente; un instrumento vital que se constituye en una extensión de la función coactiva del poder del Estado. Desde este planteamiento que se centra en los momentos iniciales de la fundación de la Ciudad de México durante la tercera década del siglo XVI, y desde una metodología de análisis propio de la Historia Archivística, nuestra intención aquí es dar cuenta, principalmente, de los aspectos simbólicos que envuelven al archivo de la ciudad y a los documentos que custodiaba. Un simbolismo que reforzaba la condición utilitaria o práctica del arca de tres llaves con nociones asociadas a ella como las de control, poder, privilegio o secreto. 
La fundación de la Ciudad de México por parte de Hernán Cortés adquirió en el continente americano una dimensión única respecto a otras fundaciones por los precedentes históricos de los mexicas, que habían creado una ciudad, según el propio Cortés manifiesta en su cuarta relación dirigida a Carlos V fechada el 15 de octubre de 1524, de "grandeza y maravillo asiento"; por ser un fundación pionera que conllevó el dominio de toda la Nueva España y la consiguiente emisión de dispositivos legales que luego se utilizarían para gobernar otros dominios distintos de las Indias, y por el acentuado desarrollo posterior que la ciudad adquirió a partir de los códigos culturales que la Corona española impuso. Por ello, la fundación de la Ciudad de México resulta ser modélica para nuestras intenciones y es la que utilizamos ahora para interpretar su archivo fundacional como un mecanismo de poder práctico y simbólico cuya documentación inicial, sobre todo sus actas capitulares, nos dan testimonio de la gestación de un nuevo orden que se sirve del traslado de la tradición hispana burocrática para instalarse y perpetuarse desde una determinada y concreta traza urbana.

La consulta de las actas originales escaneadas que custodia el Archivo Histórico de la Ciudad de México, contrastada luego con la transcripción de las mismas que publicó Ignacio Bejarano a través de la Colección Digital de la Universidad Autónoma de Nuevo León (México), son la base de esta investigación que se nutre posteriormente de una esencial bibliografía en busca de interpretaciones que apoyan nuestra inicial consideración del arca de tres llaves fundacional como una estructura simbólica depositaria de códigos orgánicos y racionales que, en nombre de la Corona española y desde la institucionalidad que le daba sentido, podía desplegar sus facultades impositivas de dominio, control y orden. Una construcción estructural simbólica en la que elementos íntimamente conectados como el ejercicio escribanil, el documento escrito y el archivo que lo custodia dan sentido a una compleja red de hechos y relaciones que la escritura legitima.

\section{La instalación del arCa de tres llaves en el Cabildo, Justicia y Regimiento de la Ciudad de México}

Los documentos pictográficos indígenas de México, junto con las interpretaciones de algunos de ellos y otras tradiciones de producción escrita en alfabeto latino después de la Conquista, permiten hablar de "historia" propiamente dicha para los dos o tres siglos anteriores al dominio hispano. Los mexicas de México-Tenochtitlan se habían convertido en el principal grupo 
dominante de la zona y su cultura y sistema político son el antecedente inmediato anterior a la Conquista. Explican, por tanto, el proceso de la misma Conquista y la manera en que el régimen colonial utilizaría las instituciones sociales aborígenes (Carrasco, 1981).

El centro de México, cuando llega Hernán Cortés, incluía una gran variedad de pueblos de diverso origen, sin unificación política pero con señoríos básicamente semejantes que permiten considerar a la región como una unidad desde el punto de vista de sus componentes culturales y de sus instituciones sociales. ${ }^{1}$ Una unidad cultural que la conquista de la Ciudad de México debía convertir a los valores dominantes de la Corona española mediante su gobierno y administración. Una vez conquistada, la Real Cédula emitida en Valladolid por Carlos V el 15 de octubre de 1522 concede el título de Gobernador y Capitán General de la Nueva España a Hernán Cortés, y le da derecho a administrar "justicia civil y criminal" en sus "ciudades, villas y lugares", y nombrar para ello y para su "buena gobernación” alcaldes, lugartenientes, alguaciles y otros oficios "anexos e concernientes" (León-Portilla, 1964: $132-135)^{2}$

La importancia que ya poseía Tenochtitlan entre los mexicas ofrece suficientes razones a Cortés para reconstruirla después de su conquista y reedificar sobre ella no sólo un nuevo armazón urbanístico y arquitectónico, sino también un nuevo sistema político y cultural:

[...] viendo que la ciudad de Temixtitan, que era cosa tan nombrada y de que tanto caso y memoria siempre se ha hecho, pareciónos que en ella era bien poblar, porque estaba toda destruida; y yo repartí los solares a los que se asentaron por vecinos, e hízose nombramiento de alcaldes y regidores en nombre de vuestra majestad, según en sus reinos se acostumbra; y entre tanto que las casas se hacen, acordamos de estar y residir en esta ciudad de Cuyoacán, donde al presente estamos. De cuatro o cinco meses acá, que la dicha ciudad de Temixtitan se va reparando, está muy hermosa, y crea vuestra majestad que cada día se irá ennobleciendo en tal manera, que como antes fue principal y señora de todas estas provincias, que lo será también de aquí adelante; y que se hace y hará de tal manera que los españoles estén muy fuertes y seguros y muy señores de los naturales, de manera que de ellos en ninguna forma pueden ser ofendidos. (Tercera carta-relación dirigida al emperador Carlos V, Coyoacán, 15 de mayo de 1522. Cortés (1988: 165))

1 Hay que evitar, no obstante, "asimiliar los mundos indígenas con totalidades estables, con sociedades monolíticas e inmóviles, totalitarias antes de tiempo o anclados milagrosamente fuera de la historia". Pueblos no homogéneos, "antiguos y autóctonos coexistían con los recién llegados, que adquirían las tradiciones locales al mismo tiempo que prestaban sus servicios" (Gruzinski, 2007: 16-17)

2 Real Cédula del 15 de octubre de 1522, nombrando a Hernán Cortés "gobernador e capitán general de toda la tierra e provincias de la [...] Nueva España e de la ciudad de Temistitlán". 
Tres son los hechos relevantes de esta relación que se envuelve de oficialidad al ser un comunicado al rey para dar testimonio de que sus actos se ajustan a la legalidad del momento. El primero, los repartimientos de solares para poblar la ciudad con asentamiento de nuevos vecinos. El segundo, el establecimiento de una organización política que conformará el Cabildo, Justicia y Regimiento de la Ciudad de México con el nombramiento de alcaldes y regidores en nombre de la Corona y, como la tradición obligaba, "en nombre de vuestra majestad, según en sus reinos se acostumbra". Y el tercero, la intención de reconstruir una ciudad que desde sus características de "grandeza" ("principal y señora") ofrezca garantías de seguridad a los españoles frente a los naturales.

La capital del nuevo Estado será la misma del México vencido, hecho simbólico con el cual Cortés utiliza las costumbres del reino de Castilla para construirse una legitimidad ya no sólo a los ojos del rey de España, algo que había sido una de sus principales preocupaciones durante la campaña de conquista, sino frente a la población local, encarnado la continuidad con el reino de Moctezuma (Todorov, 1987). ${ }^{3}$

Antes de la Conquista de Tenochtitlán, Cortés ya había ejercido, bien como "auxiliar de pluma", bien como escribano responsable, en distintos momentos y lugares durante un considerable tiempo de 10 años y era consciente de la legitimidad que, ante la Corona, representaba el documento escrito para dar legalidad a los actos que se llevaban a cabo en territorio indiano. ${ }^{4}$ Además, desde 1519, tenía establecidos algunos cabildos nombrando alcaldes y regidores: "[...] y viendo cómo yo tenía ya pobladas tres villas de españoles" (Tercera carta-relación. Cortés (1988: 165)).

El poder que el 20 de diciembre de 1522 Cortés otorga a los primeros procuradores que envió a España habla del primer cabildo que tuvo lugar en Coyoacán. Pero sólo de 1524 son las noticias que mencionan a las primeras autoridades de la Ciudad de México: un alcalde mayor, un alcalde ordinario, cinco regidores y un escribano (Archivo Histórico de la Ciudad de México [AHCDMX], acta de 8 de marzo de 1524). ${ }^{5}$ Las primeras sesiones del cabildo de la nueva fundación de la Ciudad de México, todavía sin edificio propio, se realizaron en casas particulares, como las del propio Cortés y las de distintos cabildantes, y en establecimientos religiosos como iglesias y conventos. La

3 El virrey Mendoza, como ejemplo, volverá a utilizar los registros fiscales del imperio azteca.

4 Sobre el tiempo de 10 años y los distintos lugares, tanto españoles como en las nuevas fundaciones indianas, de ejercicio como escribano de Cortés, consúltese Pérez (2009: 75-91).

5 Citamos la fecha de las actas que se encuentran en el AHCDMX, que pueden consultarse en la transcripción pública virtual de las mismas (http://cdigital.dgb.uanl.mx/la/1080018068_ C/1080018068_C.html): Actas de Cabildo de la Ciudad de México (s. a.). A partir de ahora se indicará en cita la fecha del acta en cuestión. 
primera sesión del cabildo registrada en las propias “casas del concejo”, para cuya construcción Cortés asignó seis solares, fue celebrada el 16 de julio de 1526. La construcción del edificio del cabildo se inició, probablemente, a fines de 1523, en la esquina de la Plaza Mayor y la Calle de San Agustín. ${ }^{6}$

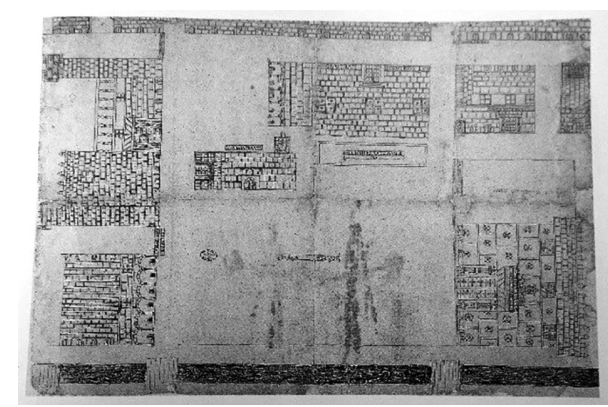

Figura 1. Plano de la plaza mayor de la Ciudad de México (ca. 1566). Anónimo. El edificio almenado por el lado derecho es el palacio virreinal o casas nuevas de Cortés. Las construcciones con torres del lado izquierdo son las casas viejas. Archivo General de Indias, Sevilla.

Fuente: Castro Morales (1998: 47)

La nota marginal del acta del cabildo de 10 de mayo de 1532 (AHCDMX) nos dice que "Este día se hizo el primer cabildo en las casas nuevas de cabildo". Posiblemente no fue hasta esa fecha que el cabildo comienza a sesionar con regularidad dentro de un edificio nuevo y propio. Pero antes, en el acta de 29 de noviembre de 1529, ya se habla de "una puerta que se hizo para la cámara donde a de estar el arca del cabildo". La mención al archivo o arca de tres llaves y a las medidas de seguridad donde ésta debe resguardarse, reforzando las propias medidas del arca triclave, es indicio de que ya desde antes (la primera acta conservada es de 8 de marzo de 1524) se estaba gestionando una documentación recibida y producida por el propio cabildo en el ejercicio de sus funciones. El acta de 24 de julio de 1531 confirma la existencia de una "arca que [Juan Francisco carpintero] hizo para el cabildo para los libros dél”, y en noviembre del mismo año los cabildantes deciden, al parecer para aumentar la capacidad física de archivo, comprar por 20 pesos de oro a Martín de Aburruza "un cofre de Flandes grande" (AHCDMX).

6 Para saber de los orígenes y la historia de las "casas del concejo de México-Tenochtitlan", así como de las primeras noticias de la instalación del arca de tres llaves, véase Castro Morales (2004). La versión previa e ilustrada se titula El antiguo palacio del Ayuntamiento de la Ciudad de México (Castro Morales, 1998). Sólo utilizamos las mayúsculas cuando se indica el nombre completo de la institución: Cabildo, Justicia y Regimiento. 


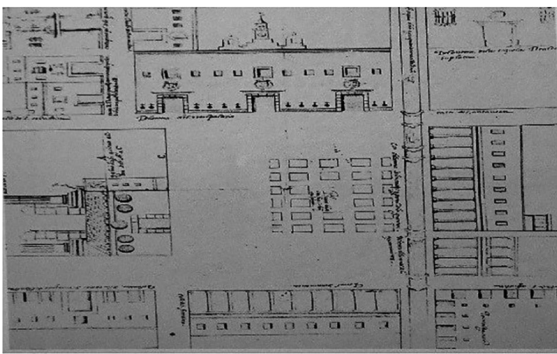

Figura 2. Plaza mayor de la Ciudad de México (ca. 1595). El edificio del ayuntamiento aparece en la esquina inferior derecha. Archivo General de Indias, Sevilla Fuente: Castro Morales (1998: 57)

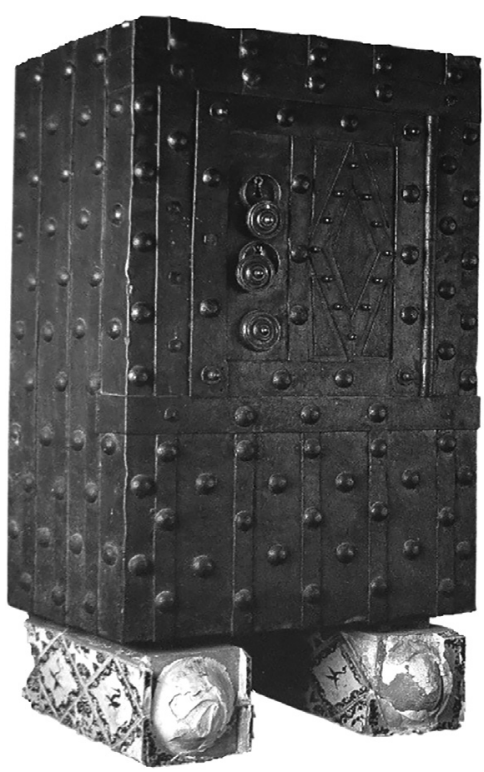

Figura 3. Arca de tres llaves. Museo Bello, Puebla Fuente: Castro Morales (1998: 41)

Fue la Pragmática de Corregidores de los Reyes Católicos de 9 de junio de 1500 la que institucionalizó el "arca triclave" como archivo de los concejos. En ella se acomete una amplia y rigurosa reglamentación del gobierno local, obliga a los corregidores a hacer en las villas o ciudades un arca en la que se custodien sus privilegios y escrituras, y encarga al escribano del concejo la custodia en la misma arca de los libros de las leyes del Reino: "haga que en la dicha arca esten las Siete Partidas, y las leyes del Fuero, y este nuestro Libro, y las mas leyes y pragmáticas, porque habiéndolas, mejor se puede guardar lo contenido en ellas" (Novísima Recopilación, 1993 [1805-1807]: Ley II, Título II, Libro VII). 


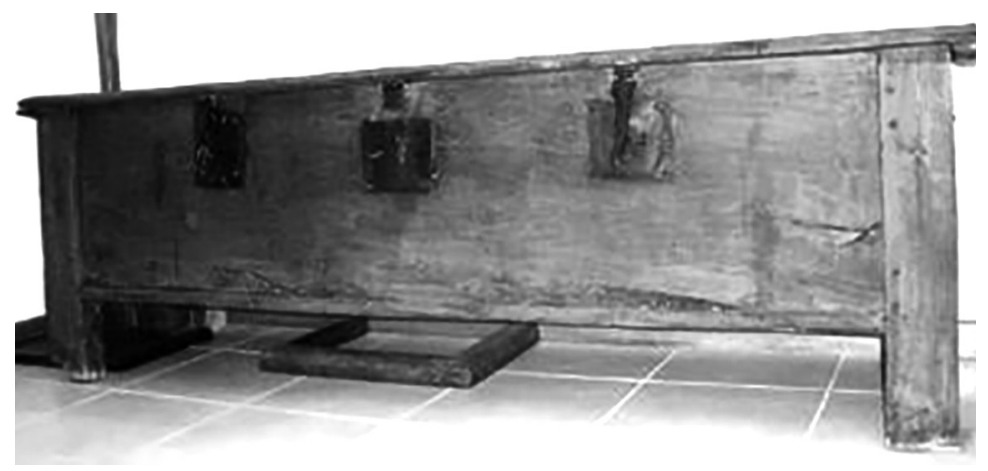

Figura 4. Arca de privilegios de la tradición archivística española de la población de Ventrosa (La Rioja, España)

Fuente: http://www.larioja.org/archivos-municipales/es/arca-privilegios/galeria-imagenes

La regulación establecida para los reinos de la Península no va a ser diferente a la reglamentación archivística que regula la América española. Las poblaciones que van fundándose durante la conquista y colonización del territorio americano recibirán sucesivas disposiciones generales para regular sus archivos de cabildo o municipales y serán plasmadas en la Recopilación de Leyes de los Reynos de las Indias (1943 [1791]). Una Real Cédula de 24 de julio de 1530 dada por Carlos I y otra de Felipe II de 1 de septiembre de 1548, incluidas ambas como Ley XXXI, Título I del Libro II, ordenan a los cabildos y regimientos recoger la documentación legislativa (Cédulas, Provisiones, Ordenanzas o Instrucciones) y "demás escrituras y papeles" que conciernen a sus comunidades, se haga inventario de la misma y se deposite en un archivo $\mathrm{o}$ arca de tres llaves que deben repartirse entre el alcalde ordinario, uno de los regidores y el escribano del cabildo (Recopilación, 1943 [1791]: Ley XXXI, Título I, Libro II).

En la época de la que hablamos, el arca "era una gran caja de madera con la tapa sujeta con goznes que se cerraban con una o dos cerraduras. Las otras llaves que se requerían implicaban generalmente el uso de candados" (Guajardo-Fajardo Carmona, 1995: 217). Una definición más exacta de estas arcas nos la proporcionan García Ruipérez y Fernández Hidalgo (1999) al estudiar los archivos municipales españoles durante el Antiguo Régimen:

Están construidas en madera, generalmente de nogal, y recubiertas en algunas partes de elementos metálicos. A ellos se unen las distintas cerraduras, en un número variable [...] y las asas para su transporte. Casi en su totalidad tienen forma rectangular, y su tamaño varía notablemente, aunque siempre se suele garantizar su movilidad aun llenas de documentos, por lo que no podían ser excesivamente grandes. Algunas llevan grabadas el escudo de la localidad, inscripciones alusivas a su contenido u otros elementos decorativos. Las fuentes se refieren a ellas 
generalmente como "arcas", aunque no faltan otras denominaciones tales como "arcón”, "cofre”, "cajón”, “caxa”, etc. (124)

A partir de la primera noticia señalada de 1529 , que da cuenta del arca de cabildo en la Ciudad de México, las sucesivas actas capitulares que recogen noticias sobre ella se refieren principalmente a la obligación de custodiar la documentación, a la formación de inventarios documentales y a la posesión de las tres llaves del arca. Siempre en relación a la legislación vigente, el acta del 16 de septiembre de 1555 es buena muestra de los asuntos que generalmente conciernen al archivo. Dicho día, los jueces y regidores de la Ciudad de México convinieron en la necesidad de que "halla buen recaudo en las escrituras deste ayuntamiento cedulas y provisiones de su magestad e libros de los cabildos que se hacen". Para ello y como era costumbre, se ordena que "dichas escrituras y libros [...] esten en el arca de las tres llaves [...] las quales tenga la una uno de los señores alcaldes e la otra un regidor el mas antiguo y la otra el escribano deste ayuntamiento". Se prohíbe, asimismo, sacar "escritura alguna contra lo que dicho es so pena de privacion de los oficios a las personas que tienen las dichas llaves" (AHCDMX, acta del 16 de septiembre de 1555). ${ }^{7}$

Los libros de cabildo, donde queda registrada la tipología más emblemática producida por esta institución; las actas capitulares, y las reales provisiones y reales cédulas, dos de los principales documentos legislativos del momento emitidos por la Corona real y cargados, por tanto, de simbología relacionada con el rey, serán tres relevantes tipos documentales para los cuales expresamente se había institucionalizado el arca de tres llaves.

7 A lo largo del tiempo, como era habitual también en otros cabildos, la responsabilidad en la posesión de las llaves podrá ir variando. En noviembre de 1582 veremos como responsables de las mismas a un regidor, al escribano y al corregidor (acta de 16 de noviembre de 1582). En enero de 1583 serán el corregidor, el alguacil mayor y el escribano del cabildo (acta de 8 de enero de 1583). En mayo de 1592, el corregidor, el escribano y el procurador mayor (acta de 15 de mayo de 1592). El procedimiento fue similar en los cabildos de Nueva España. La noticia más temprana sobre el archivo del cabildo de la ciudad de Puebla nos dice que en marzo de 1534 se encargó al corregidor Hernando de Elgueta mandar hacer un arca con dos llaves, una para el alcalde y otra para el propio corregidor. El 14 de abril de 1545 se ordenó nuevamente adquirir "un cofre para las escrituras de la ciudad" y diez años después, en enero de 1555, seguramente con más legislación al respecto y más conocimiento sobre ella, vemos que se vuelve a tratar el asunto para hacer una "caja de tres llaves" donde se guardarían "todas las provisiones que competen a la ciudad, los libros de leyes, de votos y otras cosas". Las llaves estarían en posesión del alcalde, un regidor y el escribano del cabildo (actas del cabildo de la ciudad de Puebla de 28 de marzo de 1534; de 14 de abril de 1545 y de 2 de enero de 1555. Castro (1990: 8-9). Las cursivas son nuestras. 


\section{REMEMBRANZAS: LA REPRESENTACIÓN}

DEL REY EN LOS DOCUMENTOS DEL ARCHIVO

La importancia para la monarquía española del uso consciente de símbolos que hiciesen presente al rey ausente se pone de manifiesto en lo dispuesto en el cabildo de la Ciudad de México del 3 de junio de 1557 con motivo de la entronización del rey Felipe II, para que dicho cabildo "jure, tenga y obedezca al rey don Felipe nuestro señor por verdadero rey y señor natural de los reynos de Castilla y Leon en que se incluye esta Nueba España y estados de Yndias". Se acuerda que "el dia primero de pascua de espíritu santo", a las siete de la mañana, se lleve el pendón real de las "casas de este ayuntamiento" a la iglesia mayor. El tesorero, acompañado de la "justicia e regimiento y otros vecinos y caballeros todos a caballo", debía cargar con él para colocarlo en el altar mayor de la iglesia, donde sería bendecido por el arzobispo de la ciudad. El pendón debía ir con sus mazas y entre los dos maceros un "rey de armas" con la cota y armas del rey Felipe II, sucesor del emperador Carlos V.

Acabada la misa correspondiente, los representantes del cabildo debían ascender con el pendón al cadalso que para la ocasión se había hecho en la puerta de la iglesia y enfrente de las casas reales, "donde la justica en presencia del yllustrisimo señor bisorrey presidente y oydores y prelados desta ciudad juraran en forma en un libro misal sobre los evangelios al rey don Felipe nuestro señor conforme á lo que su magestad ynperial por su real carta enbia a mandar". Con la solemnidad estipulada para el acto, el virrey Luis de Velasco alzaba el pendón de la ciudad en nombre de su "magestar real" y, a continuación, el rey de armas decía en altas voces: "castilla castilla nueba españa nueba españa por el rey don Felipe nuestro señor”. Pendones y banderas con las armas reales se colocaban por todo el dicho cadalso, en las casas reales y en las del cabildo "con mucha alegria y regocijo de musica y trompetas". Luego se hacía "salva de artillería" y "hecha la dicha solenidad y juramento", el pendón real debía volver a las "casas deste ayuntamiento" desfilando por las calles con "acompañamiento de música atabales y trompetas".

Con una separación tajante que formalmente refleja el acta capitular, a continuación se ordena que en el mismo día por la tarde, "en memoria y por alegrías de la dicha solenidad", los indios naturales "hagan su regocijo y mitote en la plaza publica y que se pregone publicamente por esta ciudad mañana sabado como se manda e a de hazer el dicho juramento e solenidad otro dia syguiente y quel dicho dia de pasqua en la noche aya por toda la cibdad calles y ventanas y azoteas luminarias y fuegos en señal de verdadera alegría”. Igualmente, más adelante, se ordena que en el segundo día de pascua "aya y se haga en la plaza de esta ciudad regocijo de toros y juego de cañas" (AHCDMX, acta de 3 de junio de 1557). 
Las manifestaciones formales que tenían por objeto la representación del rey, del gobierno y del poder recurrieron a símbolos que hacían parte de una determinada mentalidad colectiva durante los siglos XVI al XVIII. Cobraban significado dentro de un sistema de creencias que, enraizadas en una semiología religiosa, hacían posible la presencia simbólica del poder real fundamentando la teoría política de la época. Las representaciones intentaban establecer una relación recíproca o pacto político entre el rey y sus vasallos que llevaba implícita la obligación de servir y defender a su señor con sus riquezas y acciones y hasta con la propia vida. En la América colonial, esa obligación política se tradujo en un pacto preciso que supuso un compromiso individual con una persona concreta, el rey (Guerra, 1994).

El campo de lo simbólico podía albergar desde el objeto material hasta los ritos o ceremoniales de la coronación para llegar, mediante ellos, a la idea abstracta de monarquía que, en los territorios americanos, debía lograr, además, hacer presente la ausencia del rey. ${ }^{8}$ En la monarquía española, desde Carlos V, fue objeto de discusión la manera de evitar la ausencia de un rey que estaba distante en todos los reinos americanos que gobernaba. Los rituales "en nombre de su Majestad" pretendieron legitimar la hegemonía de un Estado monárquico a partir de ficciones que trataban de establecer un centro simbólico de armonía frente a una realidad disonante y creaban espacios de escenificación jerárquica de los cuerpos y autoridades que componían la sociedad urbana. El hecho de que en América "el Rey genuino no fue nunca producido como un original sino más bien re/producido, su simulacrum -o copia para la cual no existe un original- convirtió al Rey español en un monarca hiperreal". Estas representaciones, sin embargo, siempre fueron auténticas o verdaderas, pues como el referente nunca fue visto en América, el simulacrum era verdadero en virtud de esta ausencia. Por ello, este simulacrum debe ser entendido como principio central del ejercicio del poder monárquico y fue el verdadero rey de los americanos, creando una imagen de autoridad no muy distinta de la imagen de un dios: "podía verlo todo pero nunca ser visto en persona". El rey estaba presente pese a que su corporeidad sólo podía ser imaginada y representada en retratos, sellos, emblemas, documentos, insignias reales, actos rituales y ceremonias alrededor de la figura del monarca (Osorio, 2004: 8-9 y 34-35).

Se impulsó una "construcción de la Majestad Real" a partir de gestos y escenarios en larga sucesión que posibilitaban la percepción y el reconocimiento de una monarquía que se hacía "sensible" en signos externos de na-

8 Sobre los componentes del "símbolo" (objeto o imagen, significación, referencia simbólica y sujeto interpretativo), el proceso de desarrollo simbólico y los tipos de símbolos, consúltese García Pelayo (1991: 987-1031). 
turaleza simbólica. Se creaba una imagen real difundida mediante distintos medios de propaganda que buscaban principalmente conservar una buena reputación del rey y su monarquía. La propaganda monárquica de la que habla Bouza (1998) se basaba en la construcción de imágenes visuales, textos, e incluso en la misma oralidad como soporte de ideas que se convirtieron en mensajes empleados, recordados y acatados. Las imágenes del rey y los pequeños rituales o grandes ceremoniales en torno a su figura (la más importante, la practicada en las ciudades sede de Audiencia, cuando era recibido el sello real, concebido como el auténtico cuerpo del monarca, y recibido siguiendo un ritual digno de la misma persona real) tuvieron la particularidad de lograr a un mismo tiempo hacer presente al rey en todos sus estados y acordar universalmente a sus vasallos su fidelidad y reverencia.

Si bien, por un lado, los rituales cívicos y religiosos tenían con frecuencia un escenario público y abierto como normalmente lo fue la plaza de los centros urbanos, donde los símbolos reales eran asequibles y legibles a la población y cumplían una función didáctica y concienciadora, y donde también se hacían posibles los momentos de "negociación" o de "ajuste" del "pacto social"; por otro lado, los rituales institucionales relacionados con los documentos reales (cédulas, provisiones, cartas, órdenes) y el archivo del cabildo (el arca triclave) que debía custodiarlos fueron rituales internos que generalmente tenían lugar dentro de la propia institución, aunque sus contenidos informativos pudieran transmitirse públicamente a través de intermediarios orales como los pregoneros, o intermediarios escriturarios como los edictos o bandos.

En consonancia con la invisibilidad del archivo, con su carácter reservado y secreto, actos, así decía la documentación de la época, "según lo prevenido por Su Majestad", como la posesión de las mismas llaves del arca en manos de quienes representan el poder judicial, gubernativo y escriturario (alcalde, regidor y escribano), los momentos de apertura y cierre de la misma, el traspaso de los documentos de los alcaldes o escribanos salientes a los entrantes, o el juramento a las disposiciones reales, seguían simbolizando, sin ser visibles generalmente al exterior, conceptos que tenían presente la figura del rey y la obediencia a la monarquía. Sin posibilidad de cambio alguno hasta que una nueva normativa no dictase lo contrario, los códigos institucionales que envolvían al archivo de las ciudades americanas, procedentes de la tradición española, se perpetuaban herméticamente, excluidos al conocimiento de la población y perpetuados sólo por quienes tenían acceso al gobierno de las instituciones.

La imagen del rey, asociada a códigos de sumisión y obedecimiento burocrático, simbolizada en variadas tipologías documentales y en rituales que envolvían las prácticas archivísticas, penetró en todos los organismos 
oficiales, que actuaban como intermediarios entre un centro administrativo representado por la Corona y una población a la que había que transmitir los mensajes y obligaciones reales. Los autores de los documentos eran conscientes de la arquitectura formal del escrito, de la separación existente entre la "materia" (los hechos documentados) y el "ornamentum" (la escenografía persuasiva). Ya en la Edad Media, siguiendo una tradición, las cartas de Alfonso X que salían de su Corte debían transmitir la "imagen” de la Majestad Real. Las Partidas llamaban "Remembranzas" (evocaciones a la imaginación) a la representación del rey en sellos, blasones, monedas y documentos, ante su ausencia espacial y temporal:

Mandaron los sabios antiguos que no tan solamente honrasen al Rey los pueblos en qual manera quier, mas aún las imágines que fuesen fechas en semejanza o en figura dél [...] También la imagen del Rey, como su sello en que está su figura et la señal que trae otrossí en sus armas et en su moneda, et en su carta en que se emienta su nombre [...] Quien no honra estas remembranzas nin lo amaba, nin lo temíe nin lo envergonzaba nin lo obedescíe. (Partida II, Título XIII, Ley XVIII. Romero (2003: 17-18))

Como documentos emanados por la autoridad suprema, reales cédulas o reales provisiones vienen en sí mismos cargados de representaciones a la Corona que acuden a elementos derivados de su propia simbología política y jurídica: la denominada "cruz simbólica" o invocación que encabeza los documentos y los sellos oficiales del mismo "papel sellado", los formulismos documentales con su intitulación, los elementos de validación: el sello de validación real, la firma real, autógrafa o mediante estampilla, compuesta de suscripción y signatura ("Yo El Rey" más la rúbrica o signo personal) y la firma de secretarios o de otros oficiales delegados; el refrendo o refrendata del secretario, etc. Su forma es la caracterización que reviste el documento por aplicación de los requisitos o "formalidades" (sollemnia) para la perfección, tanto de la actuación escriturada, como del acto mismo de escrituración.

Además de las representaciones reales encarnadas en la factura de los propios documentos, el formalismo en cuanto al recibimiento y obedecimiento de los dispositivos legales del monarca es una prueba más del valor simbólico que adquiría la palabra del rey. Las provisiones y cédulas reales llegan al cabildo de la Ciudad de México desde sus inicios. El 2 de junio de 1525, cuando todavía se estaba construyendo el edificio que albergaría las sesiones del cabildo de la ciudad, "estando en [...] las casas e aposento del muy maginifico Señor Hernando Cortes Governador e Capitan General de esta Nueva España”, Alonso Pérez de Valera “presento una provisyon de su 
magestad por la qual le hacia merced de un regimiento perpetuo de esta Cibdad e por los dichos Señores vista la tomaron e pusyeron sobre sus cabezas e dixeron que la obedecian e obedecieron como a carta e mandado de su rey e Señor natural" (AHCDMX, acta de 2 de junio de 1525).

El 3 de junio de 1557, Melchor López de Legazpi "presento [...] provicion real e juntamente con ella una cedula de su alteza” para que, una vez examinado como candidato al puesto de escribano del consejo de la Ciudad de México, los cabildantes obedecieran y cumplieran la Real Provisión que contenía su título de escribano. Con el ritual acostumbrado, así se obedece y cumple:

[...] los dichos señores justicia e regidores vista la dicha provision la tomaron en sus manos e la besaron e pusieron sobre sus cabezas e dixeron que la obedecian e obedecieron como a carta e mandado de su rrey e señor natural a quien Dios Nuestro Señor guarde y dexe reynar por largos tienpos con acrecentamiento de mas rreynos e señorios como su rreal corona desea y en cuanto al cumplimiento dixeron questan prestos de recibir al dicho melchor de legaspi al huso y exercicio del dicho oficio e luego tomaron e recibieron juramento del dicho Melchor de Legaspi el qual lo hizo en forma debida de derecho. (AHCDMX, acta de 3 de junio de 1557)

Los dispositivos legislativos en forma de reales provisiones o reales cédulas que llegaban al Cabildo, Justicia y Regimiento de la Ciudad de México serán esenciales para dar forma legal y conveniente a sus inicios fundacionales. Su simbolismo real, además, alentará su custodia en el arca de privilegios. Las pruebas documentales (cédulas, provisiones, relaciones, autos, actas, registros de solares, informes) que la fundación de la ciudad y los actos protocolarios correspondientes generan formarán la base de un archivo que originariamente, como la legislación dictaba, a semejanza de la legislación española, será el "arca de tres llaves" (Recopilación, 1943 [1791]: Ley XXXI, Título I, Libro II). Las actas capitulares constituyen la tipología documental emblemática de una institución pública como el Cabildo, Justicia y Regimiento. Para dar continuidad a la gestión del cabildo de la Ciudad de México, en febrero de 1531, los cabildantes ordenaron

que todas las prouisiones de esta cibdad de su magestad tocantes a ella esten asentadas y se asienten en un libro blanco que se compre para ello las quales esten signadas y autorizadas y las originales esten en el arca de las tres llabes y que en un

9 Real Cédula de 24 de julio de 1530 dada por Carlos I y otra de Felipe II de 1 de septiembre de 1548, incluidas ambas como Ley XXXI, Título I del Libro II de la Recopilación 1943 [1971] 
libro de los acuerdos esten ynbentariadas las dichas escrituras que ay y la cibdad se aproueche dellas en sus tiempos e que quando alguno escritura se obiere de sacar quede por memoria en el dicho libro para que se sepa quien la lleba porque los que la llebaren tengan cuydado de las volver. (AHCDMX, acta de 3 de febrero de 1531)

El acuerdo sigue fielmente la legislación relativa a la custodia e inventariación de las leyes (cédulas y provisiones reales) que los cabildos debían obedecer y cuyas bases se encontraban en la Pragmática de Corregidores de 1500. Habla de un "libro blanco" donde debía hacerse copia autorizada de las "provisiones" recibidas y de conservar los originales en el arca triclave. En el mismo acuerdo se ordena luego comprar una "arquimesa para questé en este cabildo y en él se ponga el libro del cabildo". Un libro capitular donde sucesivamente se irán registrando no sólo los acuerdos tomados por los cabildantes, también la confección de sucesivos inventarios documentales donde se registraría el préstamo de las "escrituras". Un libro del cual debía hacerse responsable el escribano del cabildo como figura clave dedicada a la escrituración de la documentación, a su inventariación y a su custodia: "que yo el dicho escribano lo benga a sacarlo aqui y tenga yo el dicho escribano la llabe de la dicha arca por manera que nunca se saque el libro del dicho cabildo" (Novísima Recopilación, 1994 [1805-1807]: Ley II, Título II, Libro VII).

Como el resto de los documentos fundacionales, las actas capitulares, que oficialmente testimoniaban y fijaban el discurrir político de la ciudad, formaban parte del archivo que las custodiaba y que, a su vez, era custodiado por el edificio del Cabildo, Justicia y Regimiento. Lo prioritario, como indica la documentación mientras las sesiones tenían lugar en distintos espacios públicos y privados ya señalados, era contar con un edificio que debía situarse en un lugar central de la ciudad (la plaza) y albergar la sala de sesiones, la cárcel, el juzgado y el archivo, espacios que desde un doble plano, simbólico y material, estructuran el orden político, policial y burocrático de la ciudad.

$\mathrm{El}$ arca de tres llaves no tiene tan sólo un valor inmediato y práctico, también, y esto es lo relevante para nosotros dentro de un contexto más amplio de conquista y colonización, tiene otra significación: la de la implantación de una forma cultural sobre otra que posee una gran fuerza simbólica. Pero antes que ella, el edificio del cabildo que la alberga es una implantación llena de significación en virtud de que se constituye en elemento más, como el levantamiento de otros edificios institucionales, cuyo fin es el de hacer olvidar las construcciones indígenas. Antes, por tanto, que la celebración de esos rituales simbólicos en torno al rey, al gobierno o al poder, de los cuales participó el "archivo", se sitúa la traza de la ciudad y, en su centro, la plaza (o lugar central) que los cobija, un espacio central y simbólico donde el cabildo será el 
máximo representante de los poderes de una élite local ligados o legitimados por un Estado monárquico y centralista.

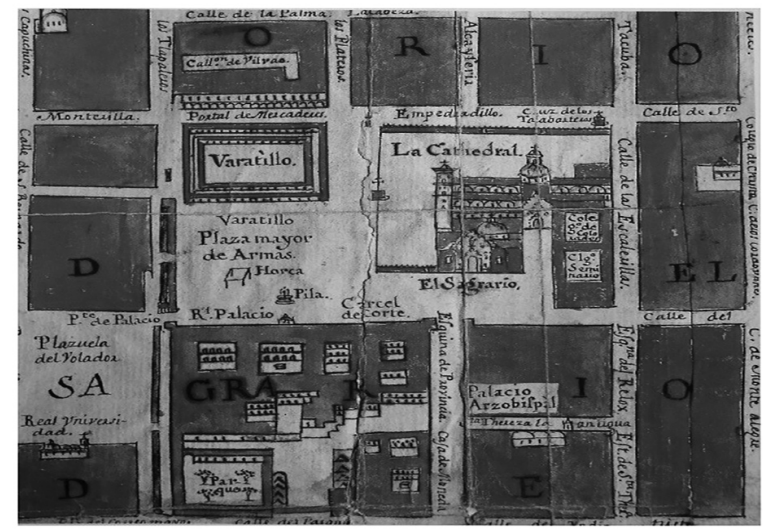

Figura 5. Detalle de un plano con leyendas donde se aprecia la Acequia Real que termina frente al callejón de la Diputación (D), es decir, el cabildo. José Antonio Álzate y Ramírez. Plano de la imperial México (1769), Museo Franz Mayer Fuente: Castro Morales (1998: 95)

La ciudad, erigida como un centro estratégico de interés geopolítico que permite el control político, judicial y económico de los intereses en juego, es considerada el espacio-soporte de la actividad humana, de las relaciones sociales que establecen los hombres; es también un espacio en el cual intervienen las dinámicas del poder. Un espacio social que, como base de la actividad simbólica, se percibe y valora distintamente por quienes lo habitan y le dan valor, que vive bajo la forma de imágenes mentales que son tan importantes para comprender la configuración de los grupos y las fuerzas que los excitan, como las cualidades reales del territorio que ocupan. Un espacio que refleja todo un conjunto de dinámicas ligadas a la obediencia y el control de las instituciones que lo administran, convirtiéndose por tanto en un obstáculo o factor limitador para la vida social de todos los individuos que lo ocupan:

El ejercicio del poder puro supone por lo tanto una organización particular del espacio; ello no es posible sino dentro de los límites de recintos en los cuales todas las partes son igualmente accesibles a quien inspecciona y cuyas salidas están guardadas de tal manera que los movimientos de entrada y salida están controlados y, si es preciso, prohibidos [...]. La articulación del espacio en áreas bien delimitadas se manifiesta [...] como correlativa del poder puro: sin esta cuadrícula, sus órdenes terminantes quedan sin aplicar. (Claval, 1978: 24-26) 


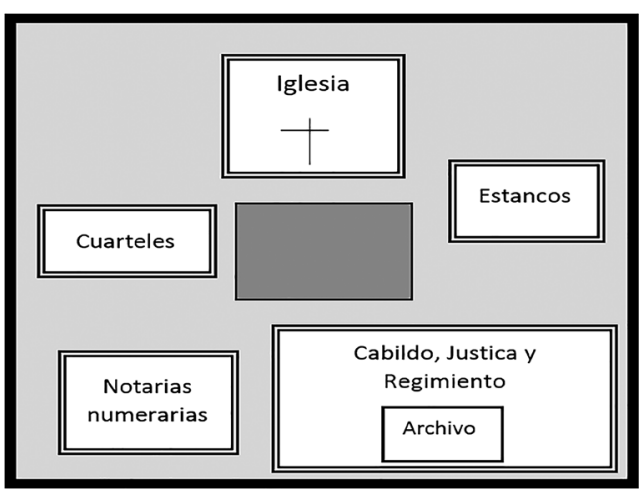

Figura 6. Clásica disposición del centro de las ciudades coloniales. Punto origen del trazado ortogonal Fuente: elaboración propia

Desde esta cuadrícula, desde la traza urbana con que los españoles reedifican o refundan la Ciudad de México conquistada, el ejercicio del poder se impuso por medio de una organización ad hoc que necesitaba transferencias incesantes de información. Las órdenes y las comunicaciones caminan de arriba para abajo en gradaciones jerárquicas institucionales y el archivo será garante de las mismas. Desde un lugar central de la cuadrícula y, a su vez, dentro de una simbólica escala de espacios concéntricos que van de la plaza al cabildo y del cabildo al mismo archivo, se dibuja una escala descendente en extensión espacial, pero creciente en su poder legitimador, que en última instancia sólo reside en el documento escrito que se conserva.

\section{Conclusiones}

El mismo proceso que inició la fundación de la Ciudad de México y constituyó su Cabildo, Justicia y Regimiento puso de manifiesto el alto grado de conciencia que se le concedió al uso del documento escrito y a su archivo. Conscientes de sus facultades como prueba y testimonio de fundamento jurídico, y conscientes de las posibilidades económicas que se estaban concentrando en el espacio geográfico donde se erigiría la ciudad con sus términos jurisdiccionales, las élites sociales y económicas interesadas en su fundación comenzaron un proceso burocrático de producción documental que hizo realidad legal una instalación institucional que, legitimada ante la ley, garantizó el control y la dominación de unos recursos dados y la apropiación privada de beneficios sociales. 
Con el fin de racionalizar y estabilizar el dominio de este espacio geográfico, la nueva fundación implicó la construcción de un modelo administrativo institucional, a imagen y semejanza de la tradición hispánica. El Cabildo, Justicia y Regimiento, la institución política e ideológica, estructurada a la Corona mediante entidades superiores como las Gobernaciones o las Reales Audiencias, dirigió el futuro de ese espacio a partir de unas estrategias que siempre recurrieron al control que les proporcionan los registros contenidos en su archivo para conseguir un orden que regulaba la vida política, hacendística, judicial o policial de la ciudad.

Con esos primeros documentos fundacionales nace el archivo que los cabildos estaban obligados a crear para custodiarlos. El carácter al parecer rigurosamente legalista de la fundación de la Ciudad de México dio inmediato cumplimiento a las disposiciones generales que se iban emitiendo para regular en territorio americano, sobre todo a partir precisamente de la conquista de la Nueva España, los archivos de cabildo o archivos municipales, disposiciones que luego serán incluidas como Ley XXXI, Título I, Libro II (Recopilación, 1943 [1791]).

Siempre en un lugar céntrico de la ciudad, pero no visible, en el archivo del cabildo reside la garantía del ejercicio del poder como depósito y medio escriturario responsable de las actividades de la Corona y de sus agentes administrativos en el nuevo continente, un instrumento que representaba la función coactiva del Estado. Actúa como un resorte institucional e ideológico que refuerza el control de quienes poseen la autoridad para mantener debajo de ella a los sujetos gobernados. La obligatoriedad del arca triclave, que en muchas instituciones municipales siguió funcionando todavía a fines del siglo XIX, suponía la existencia de un espacio cerrado y reservado, atendido exclusivamente por quienes poseían sus llaves. Al frente de él y de su organización se encontraba el escribano. La imagen del archivo, cubierta de connotaciones prácticas y simbólicas referentes a su secretismo e inaccesibilidad y relacionada con las virtudes del buen gobierno y la prudencia del manejo documental, se vio reforzada con la obligación que tenían los escribanos de hacer juramento de "sigilo y fidelidad" ante el cabildo. Su práctica burocrática los hizo receptores y productores de una diversa tipología documental que fue conformando el archivo de la Ciudad de México dentro de un enmarañado sistema político de relaciones interdependientes entre instituciones que, aunque todas ellas sujetas a un mismo poder real, actuaron cada una con una determinada práctica burocrática producto de su contexto geopolítico. 
La estancia de investigación que el Instituto de Investigaciones Bibliotecológicas y de la Información (IIBI) de la Universidad Nacional Autónoma de México (UNAM) nos concedió durante los meses de enero a marzo de 2018 ha sido el apoyo fundamental por el cual ha sido posible presentar los resultados que se muestran. Agradecemos a la UNAM, al Programa de Estancias de Investigación de la DGAPA, al IIBI y a la profesora Idalia García, quien ejerció de anfitriona en dicha estancia, sus continuas atenciones.

\section{REFERENCIAS}

Actas de Cabildo de la Ciudad de México: edición del "municipio libre" / publicada por su propietario y director Ignacio Bejarano. 1889-1907. S. a. T. I 1524-1529. México: (s. n.). Archivo Histórico de la Ciudad de México (AHCDMX). http://cdigital. dgb.uanl.mx/la/1080018068_C/1080018068_C.html

Bouza, Fernando. 1998. Imagen y propaganda: capitulos de historia cultural del reinado de Felipe II. Madrid: Akal.

Carrasco, Pedro. 1981. "La sociedad mexicana antes de la conquista", en Historia general de México, t. 1, 165-288. México: El Colegio de México, Centro de Estudios Históricos.

Castro Morales, Efraín. 1990. Memoria de la ciudad. Archivo del Ayuntamiento de Puebla. Puebla: Ayuntamiento.

Castro Morales, Efraín. 1998. El antiguo palacio del Ayuntamiento de la Ciudad de México. México: Gobierno de la Ciudad de México.

Castro Morales, Efraín. 2004. Antiguo Palacio del Ayuntamiento de México. México: Museo Mexicano.

Claval, Paul. 1978. Espace et pouvoir. París: Press Universitaires de France.

Cortés, Hernán. 1988. Cartas de relación. México: Porrúa.

García Pelayo, Manuel. 1991. "Ensayo de una teoría de los símbolos políticos", en Obras completas, vol. I, 987-1031. Madrid: Centro de Estudios Constitucionales.

García Ruipérez, Mariano y María del Carmen Fernández Hidalgo. 1999. Los Arcbivos Municipales en España durante el Antiguo Régimen. Regulación, conservación, organización y difusión. Cuenca: Ediciones de la Universidad de Castilla-La Mancha.

Gruzinski, Serge. 2007. La colonización de lo imaginario. Sociedades indígenas y occidentalización en el México español. Siglos XVI-XVIII. México: FCE.

Guajardo-Fajardo Carmona, María de los Ángeles. 1995. Escribanos en Indias durante la primera mitad del siglo XVI, t. I. Madrid: Consejo General del Notariado.

Guerra, François Xavier. 1994. "La desintegración de la Monarquía hispánica: revolución de independencia", en De los imperios a las naciones, editado por Antonio Anino, Luis Castro Leiva y François Xavier Guerra, 195-227. Zaragoza: Iberoamericana/Ibercaja.

León-Portilla, Miguel, ed. 1964. Historia documental de México, vol. 1. México: Universidad Nacional Autónoma de México/Instituto de Investigaciones Históricas. 
Novísima Recopilación de Leyes de España. 1993. Dividida en XII libros en que se reforma la recopilación publicada por el Señor Don Felipe II en el año de 1567, reimpresa últimamente en el 1775 y se incorporan las pragmáticas, cedulas, decretos, órdenes y resoluciones reales, y otras providencias no recopiladas, y expedidas hasta 1804. Mandada formar por el señor Don Carlos IV. [2 ${ }^{a}$ Reprod. facs. de la ed. de Madrid, 1805-1807]. Madrid: Boletín Oficial del Estado.

Osorio, Alejandra. 2004. El Rey en Lima: el simulacro real y el ejercicio del poder en la Lima del diecisiete. Lima: Instituto de Estudios Peruanos.

Pérez Fernández del Castillo, Bernardo. 2009. Orígenes e bistoria del notariado en México. México, DF: Porrúa.

Recopilación de Leyes de los Reynos de las Indias. 1943 [1971]. Madrid: Consejo de la Hispanidad.

Romero Tallafigo, Manuel. 2003. "Prólogo", en Actores del documento. Oficiales, archiveros y escribientes de la Secretaría de Estado y del Despacho Universal de Indias durante el siglo XVIII, Margarita Gómez Gómez, 11-20. Madrid: Centro de Estudios Políticos y Constitucionales.

Todorov, Tzvetan. 1987. La conquista de América. El problema del otro. Madrid: Siglo XXI.

Para citar este texto:

Rubio Hernández, Alfonso. 2019. "El archivo del cabildo colonial de la Ciudad de México. Fundación y símbolo de un nuevo orden”. Investigación Bibliotecológica: archivonomía, bibliotecología e información 33 (81): $135-155$.

http://dx.doi.org/10.22201/iibi.24488321xe.2019.81.58050 